\title{
The Social Burden of Witchcraft accusation and Its Victims: An Exercise in Philosophy
}

\author{
Olusegun Stephen Taiwo \\ Adekunle Ajasin University, Akungba-Akoko, Nigeria \\ shina4shinning@yahoo.com
}

\begin{abstract}
The killing and burning of witches in contemporary era seem to be unabated. The contemporary minds have not succeeded in 'scienticisng' belief in witchcraft. In Africa, Canada and India, the incidence, accusations and extrajudicial sanctions against witches are routine. The phenomenon of witchcraft is justified to be real. Before a misfortune could be plausibly attributed to witchcraft, it had to be seen as the outcome of a certain type of social situation. For in a witch-case the suspect was usually a person who had been involved in a relationship of real or presumed hostility towards the victim, then an accusation of witchcraft originated with someone living in close proximity to the suspect, and was meant to explain some local and personal misfortune. We then explain the socialization of witchcraft accusation in terms of the immediate social environment of the witch and her accuser. What we have in mind is that there are a lot of socialization between the witch and her victims in such a way that witches do not attack stranger and the victim can easily guess who is socially responsible for his/her misfortunes. We shall argue therefore, that once we are able to explain witchcraft causal reasonable explanation, the kind of metaphysical change of mind on witchcraft and the subsequent incidence, accusations and extrajudicial sanctions against witches would be reduced.
\end{abstract}

\section{Rise of Witchcraft Hysteria}

The killing and burning of witches in contemporary era seem to be unabated. The contemporary minds have not succeeded in 'scienticisng' belief in witchcraft. Witchcraft in some Western cultures is a spiritual and magical 
practice, which may have strong religious elements to it. Interest was intensified, however, by Gerald Gardner's claim in 1954 in Witchcraft Today that a form of witchcraft still existed in England. Indeed Murray wrote an introduction to Gardner's Witchcraft Today, in effect putting her stamp of approval on it.

Wicca is now practiced as a religion of an initiatory secret society nature with positive ethical principles, organized into autonomous covens and led by a High Priesthood. There is also a large "Eclectic Wiccan" movement of individuals and groups who share key Wiccan beliefs but have no initiatory connection or affiliation with traditional Wicca. Wiccan writings and ritual show borrowings from a number of sources including 19th and 20th century ceremonial magic, the medieval grimoire known as the Key of Solomon, Aleister Crowley's Ordo Templi Orientis and pre-Christian religions. ${ }^{1}$

In Africa, Canada and India, the incidences of accusations and extrajudicial sanctions against witches are routine. The phenomenon of witchcraft is justified to be real. Some people still justify the extra-ordinary power. Widows are sometimes accused of witchcraft in cases where their husbands suffered sudden or unexplainable death. It does not matter the level of education, virtually most inhabitants share in this belief: what cannot be explained, is caused by witches. If your car malfunctions, you blame the witch; if you have heart attack or stroke or other medical conditions, you blame your father's second or third wife; if you do poorly in school or if you are denied admission to the school of your choice, you blame the woman down the road. Witches are to be blamed for everything! Witchcraft was the explanation to be used when no other was forthcoming. Furthermore, witchcraft was a type of explanation that provided for the victims doing something concrete about their misfortunes. Sometimes, people could consult a cunning man, faith-healer of either Islam or Christianity, obtain (magical) remedies, and hopefully even identify and prosecute the responsible malevolent person, in this case, when the faith-healer burns some people because they are accused of witchcraft.

There are a lot of literatures on witchcraft; these include Geoffrey Parrinder, Evans Pritchard, Keith Thomas, Teresa N. Washington, Lucy Mair, Barry Hallen \& J.O. Sodipo, Sophie Oluwole, P.O. Bodunrin, Segun Ogungbemi, Akin Omoyajowo, Omosade J. Awolalu, Ade Dopemu, Blessing O. Agidigbi, Yemi Elebuibon and hosts of others.

We have gained a lot from these literatures but in this paper, I want to present some moral burden involved in witchcraft accusation. I want to argue that once we are able to explain witchcraft causal reasonable explanation, the kind of metaphysical change of mind on witchcraft and the subsequent

1 “http://en.wikipedia.org/wiki/Witchcraft" retrieved on 9 June 2016. 
incidences of accusations and extrajudicial sanctions against witches would be eradicated. We know there are a lot of socialisation between the witch and her victims in such a way that witches do not attack stranger and the victim can easily guess who is socially responsible for his/her misfortunes. But first let me explain witchcraft.

\section{The nature of witchcraft}

There are several interpretations of witchcraft. Used in different contexts in different societies and in different era, witchcraft could mean a number of things. On a conceptual level witchcraft provides an explanation for personal misfortune that is thought appropriate to a pre-scientific theoretical system. Witchcraft is associated with the supernatural, with magic and with evil deeds. Keith Thomas sees witchcraft "as the attribution of misfortune to occult human agency. A witch was a person of either sex (but more often female) who could mysteriously injure other people. The damage she might do - maleficium, as it was technically called - could take various forms. Usually she was suspected of causing physical injury to other persons, or of bringing about their death." ${ }^{2}$ The essence of malevolent witchcraft for Thomas "is the ability to inflict damage by occult means to mysteriously [non-naturally] injure other people. The injury was usually a physical one, either to the individual or to his property, and was supposedly achieved by the use of such magical techniques as (magical) physical contact, cursing, and the use of wax images." J. Omosade Awolalu asserts:

Witches (meaning àjé) are seen as the personification of evil, as innately wicked people who work harm against others. They are capable of their nefarious deeds through their possession of mysterious powers unknown and unavailable to ordinary people. All strange diseases, accidents, untimely death, inability to gain promotions in office, failure in examinations and barrenness in women, impotence in men, failure of crops and a thousand other evils are attributed to witchcraft. ${ }^{4}$

For Lucy Mair, "witchcraft ... is unambiguously evil. It may well be motivated.... But it is always held to be unjustified; the witch may have good cause for anger, but if he had not had an evil disposition he would not have

2 Keith Thomas, Religion and the Decline of Magic, (New York: Charles Scribner's Sons, 1971), 436.

3 Keith Thomas, 465.

4 J. Omosade Awolalu, Yoruba Beliefs and Sacrificial Rites, (London: Longman Publishers, 1979), $80 \& 81$. 
expressed his anger in this way." 5 Similarly Geoffrey Parrinder outlines those beliefs about witchcraft powers and behavior that he finds to be most representative of Africa generally:

The witch is generally female. She goes out at night and meets in an assembly with other witches. She leaves her body in her hut and flies to the assembly, often as an owl, other birds, or animal. The witch preys on other people and procures a victim for consumption in the assembly. The blood of the victim is sucked or its members eaten. This causes a wasting disease to his physical body, and the victim lingers until the hearts, liver or some other vital organ is eaten .... Any disease may be taken as a sign of their evil machinations. Some people believe that the witch is possessed by a witch-spirit, or has with her some witch-substance, but this belief is far from general. ${ }^{6}$

While Segun Ogungbemi believes:

The belief in witchcraft in Africa is a product of imagination and hence superstitions. It must be admitted however that witchcraft in Africa has some psychic influence on the people in spite of the fact that it is a superstition. The psychic influence of fear which witchcraft generates in African societies is more real than the physical appearance of a witch. I admit that the fear of witchcraft is a reality although no witch exists in reality. ${ }^{7}$

Witches are not addressed publicly as witches but normally euphemism are used in Yoruba land as Àwọn İyá wa (Our Mothers); Àwọn İyá mi Òsòròngà (The Great and Mysterious Mother; Yewajobi (The Mother of All the òrișà and All Living Things); Àgbàlagbà (Old and Wise One) and Aye (the Earth)." Old women are not necessarily the only ones known as witches in Yoruba. Awolalu and Dopamu explain "witches are mostly women, but men can also be found, especially at the head of the guilds. Witches usually inherit their

5 Lucy Mair, Witchcraft, (London: Weidenfel and Nicolson, 1969), 15-16.

6 Geoffrey Parrinder, Witchcraft: European and African, (London: Faber and Faber, 1970), 138.

7 Segun Ogungbemi, A Critique of African Cultural Beliefs, (Lagos: Pumark Educational Publishers, 1997), 66.

8 Teresa N. Washington, Our Mothers, Our Powers, Our Texts: Manifestations of Aje in Africana Literature, (Indianapolis: Indiana University Press, 2005), 13. 
nefarious art from their mothers. Some are born witches while other acquires witchcraft. But witchcraft can also be passed on through food."

In general witches came from the lowest rank of society. It was this class that suffered most from poverty, desperation, frustration and the helplessness that are consequent to economic and political impotence. Rather than succumbing to resignation and self-pity, assuming the role of witch offered such hopelessly downtrodden individuals some hope of power and vengeance, even if ultimately illusory. In the lower classes the position of women relative to men was weaker, making them comparatively more susceptible. Therefore, although it was usually said that men could become witches as easily as women, the overwhelming majority of accusations were made against women. No doubt many were innocent.

"Witches are believed to operate in secrecy. They have the capacity to change into birds, animals and use other unusual dresses. They go about their 'night business' while their physical bodies are on their beds. They have nocturnal meetings. The meetings are called ajo." 10 The nature of their meeting is spiritual. The witches are said to meet at night between midnight and 2.00a.m. while their physical bodies remain on their beds at home. They attend the meetings using various means of movement.

Some, according to Awolalu

are said to turn upside down and walk with their feet in the air. Some somersault to increase speed, others fly naked after rubbing on their bodies some ointment which makes them invisible. Yet others walk to the meetings on spiders' webs; some ride on animals like cats, dogs, rats or on toads and even on human beings. Many others turn into owls and lizards and into insects and glow-norms. Meetings take place at the banks of rivers, at the foot or branches of big trees or at the road junctions or on mountains or hills. It is in those meetings that they share the 'goodies' together. They plan how to get their victims and feed upon those already procured. Sucking the blood of the victim is the usual thing sought. The eating causes a wasting disease to the victim's body. ${ }^{11}$

Dealing with the myths of understanding aje, Barry Hallen and J.O. Sodipo disapproves the popular stereotype of aje as a malicious, extremely secretive person whose aim is to harass or to do serious injury to usually innocent victims. They argued that "in both Africa and the West the witch personality

9 J. Omosade Awolalu and Ade Dopamu, West African Traditional Religion, (London: Sheldon Press, 1974), 124.

10 J. Omosade Awolalu, Yoruba Beliefs and Sacrificial Rites, 85.

11 J. Omosade Awolalu, 85. 
stereotype is that of someone who is anti-social, deliberately, excessively and destructively malevolent" 12 but they argued further that the personality stereotype of the witch is negative by adding the following understanding of witch:

$\mathrm{He}$ (the onisegun - doctors) may even know medicine to the point that people may want to run from him. They will say he is aje (witch) ...

The word of mouth can make one person to be regarded as aje. There are some people who will say something and it will be like that. When he says so, it will happen like that. And you can call this kind of person any kind of name.

If someone is more brilliant than his mates, we may refer to him as aje .... There is one which could be regarded as aje. For example, if you are doing something which is always right without anyone telling you (what to do) ....

They call that kind of person àjẹ because he always says the truth. His words never miss. They will say that if his dreams are always coming to be true, people will say he has already finished everything by the night.

There are some people, called àjẹ, who are supernatural. But whenever they do any supernatural thing, if you were to ask them how it is possible for them to do such a thing, they would attribute it to the power of Olọrun (the supreme deity). Olọrun is just like something under which persons hide to apply all our powers. Olọ́run stands as a shield under which everyone hides to apply whatever power he possesses. ${ }^{13}$

Hallen and Sodipo then concluded that an àjẹ (witch) suits the popular stereotype definitions of Parrinder and Mair; [and indeed some other definitions of Awolalu, Ogungbemi, which we have considered (my word)] "as an extremely dangerous and destructive anti-social personality that must be sought out and destroyed whenever possible. On the other hand, aje may be used for the benefit, welfare, defence and development of mankind." 14 Reiterating the arguments of Hallen and Sodipo, Diedre Badejo says "... any person of ability, insight, leadership or other forms of observable power can be considered witch" (àjẹ). ${ }^{15}$ Also Awolalu observes that "people who are exceptionally

12 Barry Hallen \& J.O. Sodipo, Knowledge, Belief \& Witchcraft: Analytic Experiments in African Philosophy, (London: Ethnographica Publishers, 1986), 96.

13 Barry Hallen \& J.O. Sodipo, 104 \& 105.

14 Barry Hallen \& J.O. Sodipo, 111.

15 Teresa N. Washington, Our Mother, Our Powers, Our Texts: Manifestations of Aje in Africana Literature, 8. 
clever, successful or charming are sometimes believed to be, and are called, witches. It is common, even among schoolchildren, to nickname a boy who is usually top of his class an 'aje' (a witch). ${ }^{16}$

Consequently, the translation, 'àjẹ' - witch is singularly misleading and conceptually incorrect. In the same vein Blessing O. Agidigbi believes:

the traditional word for witchcraft is ' $n$ si ndi igbome'. In this usage, a witch or 'ogbome' is any person whose behaviour is outside the expected patterns of behaviours. Such anti-social behaviours that could earn one the stigma of being a witch include wickedness, hard-heartedness, not being fond of greeting people, committing incest, living alone in an isolated area, not showing adequate sorrow at the death of a relative or somebody from within the community and so on. ${ }^{17}$

In Agidigbi's second usage, "a witch refers to a person who practices witchcraft. It could be a person suspected by the community, a person who has confessed or a person who has been identified by witch-doctors, a diviners or fellow witches to be a witch."18

The erroneous translation of the word 'aje' meaning a witch in Yoruba, 'ogbome' in Ika land couple with the misguided assumption that complex African concepts can and must be defined by false European language equivalents hassled too much confusion and impeded a true understanding of the word. The pervasive myth of 'African witchcraft' was imported from Europe with all its attendant evil, patriarchal iconoclasm and devilishness. It finds constant validation in the African mass media which feeds off into societal indoctrination.

Thus, conceptualization of 'àjẹ' or 'ogbome' is also complicated by the fact that it is not a one-dimensional concept or figure with a neat definition or concise exposition. Ubiquitous, ambiguous and invisible, 'àjẹ' or 'ogbome' is everything; it is nothing. Its depth, breath and shroud of taboo and secrecy may be reason for this.

\section{The Social Burden of Witchcraft Accusations and its Victims}

The first feature which emerges from a scrutiny of witchcraft accusation is an obvious one, this is the fact that it was excessively rare for human beings to decide that they had been victims of witchcraft without also having

16 J. Omosade Awolalu, Yoruba Beliefs and Sacrificial Rites, 88.

17 Agidigbi O. Blessing, "Witchcraft in Ika Traditional Thought and Contemporary Change”, Ekpoma Journal of Religious Studies, 5: (1\&2), June, 2003, 82.

18 Agidigbi O. Blessing, 82. 
a particular suspect in mind. "There is the people's readiness to believe that witches are the causes of the problems and that everything will be well once they are rooted out."19

Witchcraft accusation is a product of suspicion. If, for example, a man's son goes to visit his aunt during holidays, and the boy is taken ill and dies, there is nothing to exempt the aunt the boy is visiting from the accusation of witchcraft. Most people would suspect that she is a witch who has killed her nephew. On another case, if someone becomes ill or is overtaken by any calamity soon after an argument in which threatening words were used, the chances are that his/her misfortune or mishap will be attributed to the person who used threatening words.

Witchcraft accusation may, sometimes, be a result of jealousy. If the children of one of the wives of a man prosper while those of the other wives (in a polygamous home) do not, this will be attributed to witchcraft. Boasting invites jealousy. A well-to-do or fortunate person who boasts of his/her prosperity or wealth will be envied in a society where many are poor. ${ }^{20}$

Having hit upon magic as the explanation for their misfortunes, it does not seldom take people long to identify the probable witch. Usually the people knew at once who it must have been. The scenario above creates "the tendency to see the witch as a victim of social forces that are beyond her control, an involuntary scapegoat who is forced to confess to excesses that are patently empirically impossible, thereby highlighting in an indirect manner the underlying social problems for which the society must victimize her."21

The dispositions above which, sometimes survive to accompany the indictments, show that the accuser established the witch's identity in one of a few standard ways. Usually the victim would recall a threat uttered by someone with whom s/he had recently quarreled.

In some cases, the victim, or his/her family, did not identify the witch unaided. Instead they invoke the aid of a white witch - àjé funfun, cunning man/woman, astrologer, or (the onísègun - doctors) or witch-doctors, or wise woman or a faith-healer of either Islam or Christianity, - who was believed to possess the magical or prayer skill necessary to identify the source of misfortune. The victim describes his symptoms and invites a diagnosis. After having recourse to one of a variety of magical aids or prayers, there would be pronouncement as to whether or not the victim was bewitched, and indicate the identity of the evil-doer. This suggests that the responsibility for the identification and even for the original suspicion of witchcraft, lay not with the

19 Keith Thomas, Religion and the Decline of Magic, 458.

20 J. Omosade Awolalu, Yoruba Beliefs and Sacrificial Rites, 87, 88.

21 Barry Hallen \& J.O. Sodipo, 95. 
victim but with any white witch - aje funfun, cunning man/woman, astrologer, or (the onísègun - doctors) or witch-doctors, or wise woman or a faithhealer of either Islam or Christianity.

Some of these white witches - àjé funfun, cunning man/woman, astrologers, or (the onísègun - doctors) or witch-doctors, or wise woman or a faithhealer of either Islam or Christianity plants suspicion of witchcraft where there is none. They can denounce persons who would not otherwise have been suspected. This, no doubt encourages accusations of witchcraft which might otherwise never have been made. They seem to have a near-monopoly of techniques for dealing with diagnosing witchcraft. This seems to be rampart as we have the case of 110 children killed by Bishop Sunday Okon Williams in Akwa Ibom over the process of exorcising the spirit of witchcraft from them.

Sometimes, the inability to assess situations correctly leads to attributing failure to witchcraft. A man who eats unripe fruit and develops acute belly-ache, may attribute his ache to witchcraft rather than to the eating of the fruit. Likewise, a man who lacks academic ability beyond high school level, but who desires to get into a university, may blame his failure to gain admission on witchcraft rather than on his natural limitations. ${ }^{22}$

Also, sometimes, refusal of alms was the most characteristic way in which the witch's supposed victims had failed in their obligations towards her so the witch retaliates. Another cause of offence was a failure to invite the witch to some common celebration. In the village community, a man or woman has a social duty to invite his/her neighbours to participate in their christenings, funerals, house warming, wedding ceremony, family festivals, etc. Guests attended such occasions as of right, and it was a positive slight to refuse an invitation to anyone who was eligible.

Witches only act on their relations and not on strangers. In other words, strangers do not become a prey of witches. They result to using their children or husbands or relations because of the fear that if after they have enjoyed the contributions of others, if they fail to bring theirs, they will be killed. If a witch wants to be held in a high esteem among her peers, she needs to bring the most successful among her relations e.g. husband, daughter, etc. she may appear wretched physically but among her peers at night she is the most prominent - a personality to be reckoned with. Giving her account, one Gloria has this to say " ... the growth or progress of any member of the cult is determined by the number of the people he or she is made to suffer or able to kill." ${ }^{23}$ Witches lived in the same neighborhood, usually in the same village.

22 J. Omosade Awolalu, Yoruba Beliefs and Sacrificial Rites, 88.

23 Johnny Danjuma, "I afflicted my husband because of N120,000 loan", The Nation, Saturday April 18, 2009, 18. 
The witches in other words, already had some sort of relationship with her victim before she was believed to have begun to practice her malice.

In all these signs of accusations, we could infer that the occurrence of a personal misfortune for which no natural explanation was immediately forthcoming, the witch is blamed. While the second, is the awareness on the victim's part of not doing either through greetings, refusal of alms or failure to extend invitation for celebration. We can conclude that the procedure followed in the witch accusation reminds us at every stage that human beings seldom seek a high degree of proof for what they already believe to be true.

Before a misfortune could be plausibly attributed to witchcraft, therefore, it had to be seen as the outcome of a certain type of social situation. This was why it was very unusual for large-scale disasters, like famine, plague or fire, to be blamed on a witch. For in a witch-case the suspect was usually a person who had been involved in a relationship of real or presumed hostility towards the victim. But the victim of an epidemic of cholera or cerebro-spinal meningitis in Kaduna, Adamawa or an Ogunpa flood in Ibadan, etc., was not an individual or a family, but a whole community. To be plausibly suspected of bringing about such a disaster, it would be necessary to stand in a relationship of hostility, not to this or that individual, but to the community as a whole. The guilty party could only be someone whom everybody was conscious of having being ill-treated. An old woman might conceivably be the enemy of a small community, but she could hardly be suitable adversary for a city or a whole nation. Epidemics were sometimes thought to have been stimulated by national enemies; they played virtually no path in fostering accusations of witchcraft. Fire was neither blamed upon witches as we have of the Enugu - the New market in Enugu or Balogun market in Lagos state, for instance.

Witch-belief, in other words, does not explain misfortune in general, but only in particular. It has an altogether different social function. An accusation of witchcraft originated with someone living in close proximity to the suspect, and was meant to explain some local and personal misfortune. Before a witchcraft accusation could be plausibly made, the suspect had to be in a socially or economically inferior position to her supposed victim. Only then could she be presumed to be likely to have had recourse to magical methods of retaliation, for, had she been the stronger party, more direct methods of revenge would have been at her disposal. This is why there are hardly any case in which the witch was socially more elevated than the victim. The above gives insight to the socialization of witchcraft accusation in terms of the immediate social environment of the witch and her accuser.

Thomas argues that the circumstances of witchcraft accusation crept in a society that is technologically more backward. "Witchcraft served as a means of accounting for the otherwise inexplicable misfortunes of daily life. 
Unexpected disasters - the sudden death of a child, the loss of a cow, the failure of some routine household task - all could, in default of any more obvious explanation be attributed to the influence of some malevolent neighbour." ${ }^{24}$ Sabella Ogbobode Abidde also argues:

Africa is an inimitable continent, rich in complexities and contradictions; rich in nature's wonders, yet, filled with man-made miseries and fetidities. It is both rich and poor and is inhabited by people who are at once happy and miserable. The African life is pulled and pushed and contradicted by different poles: primeval sentiments, superstition, religion, culture, and modernity. The biggest challenge, of course, is the morbidly superstitious life fueled by poverty and ignorance. Superstition, poverty and ignorance accounts for why, many decades after most societies have progressed, the African life is still loaded with primitive passions and preliterate conditions. Belief in witchcraft and all such phenomenon is a product of deepseated fear, ignorance, backwardness, illiteracy of the mind, gullibility, self-loathe and an inability or refusal to take responsibility for ones stupidity, failings and shortcomings. The rest of Nigeria is not different in this regard: if your car malfunctions, you blame the witch; if you have heart attack or stroke or other medical conditions, you blame your father's second or third wife; if you do poorly in school or if you are denied admission to the school of your choice, you blame the woman down the road. Witches are to be blamed for everything! ${ }^{25}$

For Ogungbemi,

... it is philosophically clear that the belief in witchcraft is a product of African imagination and hence superstitious. It must be admitted however, that witchcraft in Africa has some psychic influence on the people in spite of the fact that it is a superstition ... I admit that the fear of witchcraft is a reality although no witch exists in reality. The truth of the matter is poverty, ignorance, "unscientific" and "unphilosophical" of some of African traditional life has contributed to this ill-fated belief. Witchcraft participates in religion and provides answers to metaphysical problems encountered by the Yoruba." 26

24 Keith Thomas, Religion and the Decline of Magic, 535.

25 Ogbodode Abidde, Sabella, "Witchcraft”, http://groups.google.com/group/ USA Africa Dialogue, retrieved on 9 June, 2016.

26 Segun Ogungbemi, A Critique of African Cultural Beliefs, 66-67. 
Using the argument of Paul Bohannan, Ogungbemi wants us to take this argument seriously, "most telling of all, witchcraft is a faulty logical device. Its fault lies in its premise. The premise is that human disease and death can be caused by the ill-will of another human being." 27

On her part, the witch believes witchcraft is a method of bettering one's condition when all else had failed. Witchcraft is a substitute for impotence, a remedy for anxiety and despair. Witchcraft usually involves the acts of malice toward other people. Although the witch might expect to gain some material benefits from her diabolical compact, these were subordinate to her main desire, to avenge herself upon her neighbors. Such a desire was to be found at all levels in any society, but it was usually only the poor and helpless who hoped to attain it by witchcraft, because for them the normal channels of legal action or physical force were not available. The desire for the revenge and the inaccessibility of normal agencies for achieving it, were thus the essence of the witch's predicament. ${ }^{28}$

Lowness of condition, thought Nathanael Homes, was the first ingredient in the making of a witch:

When men through crosses, wrongs, vexations, wants, etc., are in deep discontent; so that they say in their hearts, what would they not do, that they might be avenged on such and such; at such times as these, the Devil, by voice only, or by some shape also, approaches near to them, offering them aid ... upon his conditions. ${ }^{29}$

The fear of maleficium provides the normal driving-force behind witch-prosecutions. What awoke the indignation of the witch's enemies was the conviction that they were the acts of malice. "Their children feel ill, their cattle died, [....] The witch was an object of hatred to her neighbors. She was subjected to informal acts of violence, and her conviction at the assizes usually had the full support of the community from which the charge originally emanated." 30

Though Awolalu cautioned that "we must realize that even nowadays, with all the influence of Western education and improved medical facilities, one still finds accusations of witchcraft between fellow-workers who are competing for the regard of their employer, between political opponents and even

27 Segun Ogungbemi, 67-68.

28 Keith Thomas, Religion and the Decline of Magic, 522.

29 Keith Thomas, 522.

30 Keith Thomas, 460. 
among educated children of the same father." ${ }^{31}$ He then offered some observations and essential facts:

(a) that some of the so-called civilized nations of the world who tend to ridicule the concept of witchcraft in Africa and who claim that the cult is an illusion, are not sincere as there is the evidence that they are resuscitating the cult in their own countries and in their own way;

(b) that witchcraft is almost universal and it is enduring. ${ }^{32}$

\section{Universality and Endurance of Witchcraft in Contemporary Life}

The universality and endurance of witchcraft mentioned by Awolalu could be seen in most countries finding new and greater areas of application. As Parrinder notes "... in the interpretation of witchcraft today European and African beliefs are often cited together. The witch-cult theory of Europe is often said to have African parallels, and so the truths about African witchcraft need to be made plain. On the other hand, Africans often say that witchcraft must be true since Europeans believed in it once." 33

It is clear from the above submission that witchcraft - be it European or Africa would continue unabated with the use of supernatural powers, magic; and could be used to do good or evil. Witchcraft activities still continue to violate the laws of nature since witched whether in Europe or Africa can change themselves into other bodily forms, animals, etc.

Furthermore, Parrinder was optimistic in early 70's that witchcraft beliefs would disappear through modernization, Western education, etc. He notes thus;

It is sometimes said that belief in witchcraft is on the increase in these days of modern towns and new ideas, and general insecurity... Education will slowly dispel some superstitions. Medical and child care will remove many unexplained diseases. But nobler beliefs and a new religion would lift the load of false beliefs and prejudice. It took centuries for the superstition to disappear from Europe, and it will fade out in Africa in the course of the forces of enlightenment are maintained and increased. ${ }^{34}$

31 J. Omosade Awolalu, Yoruba Beliefs and Sacrificial Rites, 89.

32 J. Omosade Awolalu, 91.

33 Geoffrey Parrinder, Witchcraft: European and African, 15.

34 Geoffrey Parrinder, African Religion, (London: Upworth Press, 1969), 171. 
In addition, Merz foresaw that "witchcraft beliefs would disappear through modernization, as it was claimed they had done in Europe under the influence of Enlightenment." ${ }^{35}$

These discussions corroborate what Awolalu observed above. The Cult of Wicca which Awolalu mentioned 30 years ago is now practiced as a religion of an initiatory secret society nature with positive ethical principles, organized into autonomous covens and led by a High Priesthood in England and European countries. There is also a large "Eclectic Wiccan" movement of individuals and groups who share key Wiccan beliefs but have no initiatory connection or affiliation with traditional Wicca. ${ }^{36}$

The Western intellectual's attitude of 'thank goodness, we don't believe in the African scenario and that African society that does it is primitive, sick and inhuman ${ }^{37}$ does not hold water with the introduction of Wicca by Gerald Gardner's claim in 1954 Witchcraft Today in that the form of witchcraft still exist in England and some European countries. The Wicca is now practiced as a religion of an initiatory secret society nature with positive ethical principles, organized into autonomous covens and led by a High Priesthood. The universality and endurance of witchcraft would continue to abate. We put forward that only perfect love can cast out fear of witchcraft even as it endures.

\section{Philosophical and Moral Solution to Witchcraft}

It will be very difficult to eradicate crimes against suspected witches. Ill-educated and educated people are convinced that evil witches exist and react violently in what they consider to be self-defense. A combination of poverty, ignorance and personal jealousies leave fearful and frustrated peasants quick to blame any adverse act of fate - a dead child, a failed crop, an inheritance settlement where a sibling receives all the land - on witchcraft. The witch killings are not a problem eroded by the dribble of modernity - radios, mobile phones and cars - into villages. If anything, peasants' growing awareness of their poverty compared to the rest of the country only exacerbates tensions.

What is needed to solve the witchcraft accusation is the culture of inquiry not culture of belief. People believe witches should be burnt but can't they be forgiven as the holy books prescribe ${ }^{38}$ Can't they leave a normal life even after they have confessed? There is need for change of social reconstruction to

35 J. Merz, From Relativism to Imagination: Towards A Reconstructive Approach to the Study of African Witchcraft, Anthropos, 99:2, 2004, 573.

36 "http://en.wikipedia.org/wiki/Witchcraft" retrieved on 9 June 2016.

37 Barry Hallen, \& J.O. Sodipo, Knowledge, Belief \& Witchcraft: Analytic Experiments in African Philosophy, 118.

38 The Holy Bible, Revised Standard Version, (Enugu: World Home Bible League, 1971), Luke 7:36-50, John 8:3-11. 
establish what we want of them. The idea of faith-healers burning and accusing people with witchcraft still create social burden of not tackling the problem properly. Religion appears to exacerbate the fear of witchcraft. Instead of eradicating witchcraft, the church and mosque have exploited the belief and have been making money leaps and bounds; and helping in killing witches with impunity.

We hereby adopt Olusegun Oladipo solution which goes thus. Knowledge is the means by which human beings master and control their environment, regulate their social interactions, and indeed, distinguish themselves from brutes. But the generation, transmission and application of knowledge require a culture of inquiry. This is the culture of systematic investigations of natural and social phenomena and the use of reason to conceive of possible explanations for what we are. The culture of inquiry involves seeking and attempting to create a better world. Knowledge is a product of inquiry and, at the same time, a process of seeking to understand the conditions of our existence and to improve those conditions.

Central to this process is the capacity to examine or scrutinize, in the manner of Socrates, our cherished beliefs (of witchcraft - my word) and notions, not with a view toward the attainment of certainty, but with a view to ensuring that whatever we claim to know is supported with good reasons, or at least is reliable. In this sense, knowledge becomes a tool of self-appraisal and self-understanding without which our human search for meaning is impossible.

We do not need the culture of belief because the culture of belief (of witchcraft - my word) is the antithesis of the seeking spirit that animates the culture of inquiry. It is the culture of almost passive observation of nature and society, in which certain ways of knowing and doing things - for instance, the tendency to see, objects, events and processes as emanations from the supernatural - are taken for granted and ideas, including social practices, are received without consideration for their adequacy for prevailing circumstances. This culture is characterized by the tendency to stick with familiar ways of doing things. ${ }^{39}$

Secondly what Ogungbemi advocated thus is germane, "the philosophical courage has its foundation in education and self-affirmation. ... It is not just any kind of education that will help to eradicate witchcraft in Africa but the kind which challenges beliefs and practices with evidence." 40 What Ogungbemi has recommended seems to us to be an intellectual solution.

39 Olusegun Oladipo, Philosophy and Social Reconstruction in Africa, (Ibadan: Hope Publications, 2009), 24-25.

40 Segun Ogungbemi, A Critique of African Cultural Beliefs, 67. 
There is however this solution I want to proffer namely, a social welfare for the poor whenever they are in the society because most of the witches are from the masses, the witch murders who are apparently jobless need social welfare, and love and care rather than hatred and killing innocent witches.

Furthermore, "if witchcraft in Africa is a manifestation of general social problems, then the way to combat it is with general social programs that seek to get at its roots. The social engineering would emphasize education ('enlightenment'), improved medical services, and religious beliefs that place greater emphasis upon spiritual values ('love') that are somehow antagonistic to the fearful atmosphere in which the witchcraft phenomenon thrives." ${ }^{\prime 1}$

\section{Bibliography}

Awolalu, J. Omosade. Yoruba Beliefs and Sacrificial Rites, London: Longman Publishers, 1979.

Blessing, O. Agidigbi. "Witchcraft in Ika Traditional Thought and Contemporary Change”, Ekpoma Journal of Religious Studies, 5: (1\&2), June, 2003. Hallen, Barry \& Sodipo, J.O. Knowledge, Belief \& Witchcraft: Analytic Experiments in African Philosophy, London: Ethnographica Publishers, 1986. Holy Bible, Revised Standard Version, Enugu: World Home Bible League, 1971.

Mair, Lucy. Witchcraft, London: Weidenfel and Nicolson, 1969.

Merz, J. From Relativism to Imagination: Towards A Reconstructive Approach to the Study of African Witchcraft, Anthropos, 99:2, 2004.

Oladipo, Olusegun. Philosophy and Social Reconstruction in Africa, Ibadan: Hope Publications, 2009.

Ogungbemi, Segun. A Critique of African Cultural Beliefs, Lagos: Pumark Educational Publishers, 1997.

Parrinder, Geoffrey. Witchcraft: European and African, London: Faber and Faber, 1970.

Parrinder, Geoffrey. African Religion, London: Upworth Press, 1969.

Thomas, Keith. Religion and the Decline of Magic, New York: Charles Scribner's Sons, 1971.

Washington, Teresa N. Our Mothers, Our Powers, Our Texts: Manifestations of Aje in Africana Literature, Indianapolis: Indiana University Press, 2005.

41 Barry Hallen, \& J.O. Sodipo, Knowledge, Belief \& Witchcraft: Analytic Experiments in African Philosophy, 95. 